\title{
DE RAAD VAN JUSTITIE DES KASTEELS BATAVIA ALS MINDERE RAAD.
}

\author{
AANTEEKENING DOOR
}

Dr C. GERRETSON.

In de opmerkelijke bijdrage, waarmede Mr. J. van Kan in het vorig deel van dit tijdschrift onze kennis van de rechtsgeschiedenis der Compagnie heeft verrijkt ${ }^{1}$ ), gaat de schrijver uit van het standpunt, dat ,,in de dagen der Compagnie” de „Raad van Justitie des Kasteels Batavia” .... ,met het hoogste rechterlijk gezag bekleed was". Het geviel, dat ik van deze uitspraak kennis nam, terwijl ik doende was met de boekuitgave van een Gids-artikel, waarin ik stelde dat deze Raad, althans in Coen's tijd, slechts een ,mindere raad” was, ,een veelzins ondergeschikt, afhankelijk en plaatsvervangend hulporgaan van de Hooge Regeering, welks uitspraak" (in een door mij behandelde halszaak) ${ }^{2}$ ) ,,slechts de waarde bezat van een advies aan Landvoogd en Raden van Indië, wier college, bij aanwezigheid te Batavia, naar den uitdrukkelijken wil van den Souverein der Republiek, het hoogste en in halszaken eenig tot strafbepaling bevoegde college bleef" ${ }^{3}$ ). De tegenstelling van beide voorstellingen is frappant en mocht, naar 't mij voorkwam, niet onopgelost blijven. Doch tijd en ruimte ontbraken mij, om in de bedoelde uitgave op de zaak in te gaan. Ik moest mij dus beperken tot de toevoeging van een noot: ,ook na zorgvuldige overweging van” (Van Kan's) ,,artikel meen ik mijn voorstelling, althans voor Coen's tijd, te moeten handhaven; haar juistheid hoop ik elders aan te toonen". Aan dit voornemen ga ik hier gevolg geven.

Het belang van het geschilpunt is tweeledig. In 't bijzonder is het van belang met betrekking tot het onderwerp van mijn bedoeld

1) Het Rechtsmiddel der Revisie voor den Raad van Justitie des Kasteels Batavia, in Bijdragen, enz., D1. 102, 1e en 2 e afl., p.i., e.v.

$\left.{ }^{2}\right)$ De bekende zaak van Pieter Cortenhoeff en Saartje Speckx.

$\left.{ }^{3}\right)$ Coens Eerherstel, Amsterdam, 1944, p. 86, noot 3. 
artikel; de waardeering van het ambtelijk karakter van NederlandschIndië's stichter. Is Van Kan's standpunt juist, dan is ook juist het oordeel van De Jonge, die Coen beticht, in het proces van Pieter Cortenhoeff en Saartje Speckx ,meer dan geoorloofd was, zijn invloed op de afhankelijke rechters" te hebben doen gevoelen ${ }^{1}$ ); een betichting die, ware zij juist, een ernstige smet zou werpen op Coen's naam. Want, behoeven tekortkomingen in het particuliere leven geen afbreuk te doen aan de grootheid van een man als publieke persoonlijkheid, de gaafheid dier grootheid is onherstelbaar geschonden, zoo hij overtuigd wordt van opzettelijke krenking van een belang, in casu de administratie van goede justitie, waarvan de behartiging hem als ambtsplicht bijzonderlijk is toevertrouwd. Doch ook in 't algemeen is het geschil van belang voor de kennis van de vroegste organisatie, resp. rechterlijke organisatie der Compagnie in Indië, waarvan zooveel ons nog onbekend is.

De oorsprong van het geschil ligt wel in een ietwat uiteenloopende waardeering van een der hoofdbronnen van onze kennis van deze materie. Van Kan heeft, bij de bestudeering van zijn onderwerp, voor de allerviroegste tijden der Compagnie voornamelijk gebruik gemaakt van de voorstelling van Van Dam's Beschrijvinge, waarvan de voortreffelijke, onlangs voltooide, uitgave Stapel's voor de geschiedenis van Nederlandsch-Indië zoo vruchtbaren levensarbeid heeft mogen bekronen. Van Dam's werk is echter geen zuiver geschiedwerk in den modernen zin des woords; het is, in de eerste plaats, een handboek voor Bewindhebbers; het geeft daartoe hun destijds bereikte standpunt weer en bezigt het verleden, zoo veel doenlijk, als rechtvaardigend antecedent van de in zijn tijd vaststaande ,gronden en maximes". In werkelijkheid heeft de organisatie der Compagnie, sedert hare oprichting, een snelle ontwikkeling doorloopen, die eerst na Coen's dood tot staan begint te komen. In dat begintijdperk waren nog vele dingen onvast, die later zóó vast zijn komen te staan, dat men zich maar liever niet meer herinnerde, dat het eenmaal anders geweest was. Tot die dingen behoort ook de positie van den Raad van Justitie.

Uit die onvastheid van de organisatie der Compagnie, die aan de ,opvatting" der gezagdragers een groote speelruimte gaf, vloeide in de eerste jaren der Compagnie een zee van penibele vraagstukken voort, die men kennen moet om het beleid van een groot leider als

1) Vgl. J. K. L. de Jonge: De opkomst van het Nederlandsch Gezag over Java, 's-Gravenhage, II, 1870 , p. LXXXIII. 
Coen met billijkheid te kunnen beoordeelen. Het is geenszins mijn bedoeling, mij in die zee te wagen. Ik zal mij tevreden houden, zoohet mij gelukt, aan de hand van vrijwel uitsluitend de tot dusver gedrukte bronnen, mijn standpunt in het boven geformuleerd geschil voor de lezers aannemelijk te maken.

En voorts zal ik mij bepalen tot het stellen van eenige vraagteekens bij punten, die mij voorkomen nadere opheldering te behoeven.

Er is echter één grondvraagstuk dat wij, vóór wij overgaan tot de behandeling van ons eigenlijk onderwerp, even moeten aanroeren, omdat de quaestie van de rechterlijke organisatie er nauw mede samenhangt. Wat was het staatstype van den „Nederlandschen Staat in Indië"? De Indische Regeering oefende haar gezag uit bij delegatie van de moederlandsche; voor een juist begrip moeten wij ons dus wenden tot de Republiek. De Vereenigde Nederlanden waren tot zelfstandigheid gekomen in een tijdperk waarin een nieuwe Staatsidee, die der Staatssouvereiniteit, tot gelding was gekomen. Wilde de Republiek dus een plaats innemen als gelijkgerechtigd lid van de nieuwe Europeesche statenmaatschappij, dan diende zij zich erkenning te verschaffen als souvereine staat. Doch dat ging maar niet zoo gemakkelijk! De oorzaak daarvan lag in haar gemengden regeeringsvorm: de Prins en de Staten Generaal, wier onderlinge verhouding, ten tijde van de stichting der Compagnie en de eerste jaren daarna, nog zeer zwevend was, en nog allerlei ontwikkelingen toeliet. Volgens de theoretici van de nieuwe staatsidee, Bodin voorop, bezaten alleen die staten, welke een der drie klassieke typen, Democratie, Aristocratie en Monarchie, zuiver representeerden, de souvereiniteit; deze kwam echter aan staten met een verdeelde oppermacht niet toe. Dit standpunt was, theoretisch, volkomen begrijpelijk. Immers de idee der Staatssouvereiniteit had zich gevormd in tegenstelling met den dualistischen Staat der middeleeuwen; staten als het Roomsche Rijk, waar de oppermacht tusschen Keizer en Rijksdag, als de Republiek, waar zij tusschen Prins en Staten-Generaal verdeeld was, en deze macht dus, deels monarchaal, deels collegiaal, werd uitgeoefend door organen, die rechtens van elkaar afhankelijk waren, konden dáárom niet als souverein erkend worden, omdat de ééne drager van de summa legibus soluta potestas, waarmee de nieuwe staat stond en viel, ontbrak. Begrijpelijk dat de jaloersche buurkoningen van deze theoretische incapaciteit maar al te gaarne gebruik maakten, om de opstrevende Republiek de intrede in de Europeesche statenmaatschappij te belemmeren; begrijpelijk ook dat de Republiek, in haar 
strijd om toelating, gaarne aanleuning zocht bij het reeds lang tot die maatschappij behoorend Venetië; deze toch was, als zij, een Republiek, maar eene die in het volkenrechtelijk verkeer door den Doge monarchaal werd vertegenwoordigd.

Toen nu de Regeering der Republiek met de Compagnie te rade ging om in haar zich ontwikkelend handelsrijk een centrale regeering in te stellen, spreekt het vanzelf dat zij, juist in verband met deze moeilijkheid; er bijzondere aandacht aan besteedde, om deze regeering te bekleeden met de plena potestas, die de kracht en de klem van een modern staatsbestuur uitmaakte. In deze potestas toch was de middeleeuwsche verbrokkeling van machten overwonnen; zij omvatte, onverdeeld en onverdeelbaar, de volle besturende, wetgevende en rechterlijke macht. Geen wonder dan ook, dat, bij de resolutie van 27 Nov. 1609, deze regeering, de G. G. en Rade van Indië, wordt "gecommitteerd en onthouden om.... regt en justitie, zoo in 't crimineel als in 't civiel te administreeren". De Hooge Regeering van Nederlandsch-Indië is dus ab ovo het Opperste Rechtscollege in het handelsrijk der Compagnie. Inderdaad treden, van het begin af, G. G. en Rade ter plaatse van hun tijdelijk verblijf, als zoodanig op, waarbij hen de reeds aanwezige fiscaal ter beschikking staat. Wel krijgt in art. 1 van de gelijktijdige instructie van den eersten Landvoogd Both, de Hooge Regeering last om alle andere kantoren en kwartieren te voorzien van colleges, die daar in civiele zaken zullen recht doen; maar dit doet aan hare positie als Opperste Rechtscollege natuurlijk geen afbreuk. Waarom echter slechts ,,andere kantoren” [dan Bantam], en waarom slechts ,,in civiele zaken”? De reden is, dat de quaestie van de rechterlijke organisatie, bij de instelling van de centrale regeering, reeds niet meer in haar geheel was; geen gemeenschap, hoe klein ook, kan, hoe kort ook, buiten rechtsbedeeling. Zoolang zich de handelsvaart der Nederlanders bepaalde tot de Europeesche wateren, bleef, behoudens een beperkt disciplinair tuchtrecht van schipper of scheepsraad, de rechtspleging over de opvarenden der handelsvloot in den regel opgedragen aan den rechter in de thuishaven. De vaart op Oost-Indië maakte echter een nieuwe regeling noodig. $\mathrm{Bij}$ den langen duur der reizen was de tijdige aflevering der delinquenten aan den thuisrechter ondoenlijk; de handelsschepen der Compagnie kregen bovendien, door het verleenen van offensieve commissiebrieven, al spoedig het karakter van oorlogsschepen. Op de oorlogsvloot nu was, krachtens de ordonnanties op de Admiraliteit, de, in beginsel voor alle zaken den 
Admiraal voorbehouden, rechtspraak, voor de disciplinaire gevallen, aan den scheepskrijgsraad toegewezen. In aansluiting aan deze regeling werd nu, bij Maurits' Artikelbrief van 16 Mei 1595, de volle rechtsmacht over de opvarenden der voor Oost-Indië bestemde vloot, verleend aan den generalen scheepsraad. Wanneer dan begonnen wordt enkele kooplieden en assistenten het doode seizoen op verschillende Indische handelsplaatsen te doen overblijven, wordt dit scheepsrecht ten behoeve dezer kleine nederzettingen, mutatis mutandis, naar den wal overgebracht. Dergelijke noodrechtbankjes hebben op verschillende plaatsen, o.a. te Banda, bestaan. Slechts een ervan heeft voor ons onderwerp beteekenis; die te Bantam, waar in 1603 een groep van 9 Hollanders onder den kapitein-opperkoopman Wittert in een steenen loge wordt achtergelaten. Uit deze groep wordt een bankje van vier personen geformeerd; behalve Wittert als president, worden bij art. 3 van diens Particuliere Instructie, 3 bepaalde personen als mede-raden aangewezen; er is dus sprake van een college met, althans voor een tijd, vast personeel, dat echter, blijkbaar in het belang der rechtszekerheid, niet de volle rechtsmacht ontvangt, maar steeds slechts de civiele, d.w.z. minder belangrijke, zaken ${ }^{\mathbf{1}}$ ), mag afhandelen. De bezetting van de belangrijke, crimineele zaken moet echter wachten tot het mede achtergebleven jacht binnen is, en de koopman en schipper ervan mede in de bank zitting kunnen nemen $\left.^{2}\right)$. Er bestaan dus, van den aanvang af, eigenlijk twee verschillende colleges onder denzelfden president, die de banken spant en den eisch instelt; een breede en een smalle justitieraad; de raad van zessen is het evenbeeld van den scheepsraad; de vierschaar is een ,mindere raad".

Deze rechtbank bestaat nog ten tijde van de instelling der centrale regeering. En zij blijft, krachtens de instellings-resolutie, niet alleen

1) De delicten worden gewoonlijk in twee groepen verdeeld. Maar de twee gebruikelijkste verdeelingen leggen de snede op verschillende plaatsen. De eerste verdeeling is die in civiele en crimineele misdrijven, in welke laatste categorie dan weer een onderverdeeling wordt gemaakt tusschen niet-capitale en capitale (hals)misdrijven. De eerste verdeeling heeft het nadeel, dat onder de niet-capitale misdrijven zoowel de civiele als sommige crimineele zaken komen te behooren, wat verwarrend werkt, zooals blijkt in de uitdrukking „civiele misbruycken en capitale breucken", welke tegenstelling geen plaats laat voor delicten die nòch civiel, nòch capitaal zijn. Wij bezigen daarom de ook in de betrokken resoluties gebruikelijke indeeling in civiele en crimineele, de laatste al dan niet capitale, misdaden.

2) Vg1. Dr. H. Hoogenberk: De Rechtsvoorschriften voor de Vaart op OostIndië, 1595-1620, Utrecht, p. 137 e.v. 
voortbestaan, maar krijgt bovendien zusjes in de overige kantoren en kwartieren. Dat er in Both's instructie alleen gesproken wordt van colleges om de civiele zaken te berechten, toont aan dat men deze locale mindere raden als de permanente bases van de rechterlijke organisatie te lande blijft beschouwen; er is nog niet voldoende bekwaam personeel, om hen de berechting van crimineele, laat staan halszaken, toe te vertrouwen; en de aanwezigheid van schepen, met behulp van wier officieren men een breeder raad kan spannen komt op sommige kantoren te sporadisch voor, om er een algemeene regeling op te bouwen. Wanneer Coen nu, 13 Nov. 1614, president der Kantoren te Bantam en Jacatra met zetel te Bantam wordt, treedt hij dus ex officio tevens op als voorzitter van het Bantamsche rechtscollege ${ }^{1}$ ); de onder zijn leiding uitgesproken sententies zijn, te beginnen met die van 4 Dec. 1614, bewaard. Van het nieuwe, Opperste, Rechtscollege, merkt men, voorloopig, te Bantam niets. Geen wonder, want Reynst, die Both als landvoogd is opgevolgd, zit meestal in de Molukken. Ook de keuze, het volgend jaar, van Reaal tot provisioneel landvoogd brengt geen verandering, want ook Reaal blijft zich daar onthouden. 27 April treedt Coen voor het eerst op als voorzitter van een dergelijke bank of raad te Jacatra ${ }^{2}$ ). Maar ook wanneer Coen, 30 April 1618, zijn benoeming tot Reaal's opvolger ontvangt, blijft voorloopig principiëel alles bij het oude: want Coen stelt zijn ambtsaanvaarding uit tot zijn voorganger, die op Ternate zit, zijn ambt zal hebben neergelegd. Eerst als Coen zijn ambt heeft aanvaard, en, na het eerste beleg, op het rendez-vous is teruggekeerd, opent zich een tijdperk van nieuwe ontwikkeling.

Eenigen tijd na het bericht van zijn benoeming had Coen een 3 Nov. 1617 door de Staten-Generaal geapprobeerde instructie ontvangen, waarin ook de rechterlijke organisatie opnieuw geregeld werd. In beginsel werd daarin van Both's instructie niet afgeweken; evenmin als dit geschied was in die van Reynst, in welke de artikelen over de rechterlijke organisatie uit die van Both woordelijk waren overgenomen. G.G. en Rade houden dus (art. 8) de ,magt en authoriteyt”... ,om in civiele en crimineele en hals-zaken regt te doen, sententies te geven, en deselve, zonder admissie van eenig appèl of provocatie,

1) Vgl. Besch., IV, p. 109. De eerste maal dat Coen presideert is 28 Oct. dus nog eenige dagen vóór zijn benoeming, op 13 Nov. 1614, tot president en directeur-generaal.

2) Vgl. Besch., IV, p. 123. 
ter executie te stellen". Toch worden de voorschriften, om de organisatie beter operabel te maken, niet onaanzienlijk geampliëerd. Om tegemoet te komen aan het bezwaar, dat de Raden van Indië meestal op reis zijn en het college dus b.v. bijna nooit voldoende voltallig is om als rechtscollege te kunnen optreden, wordt de Raad van Indië, ten einde, o.a., (art. 3) den G.G. ,in het administreeren van de justitie in civiele en crimineele zaken met raad en daad te assisteeren", tot 9 leden uitgebreid, van welke de Directeur-Generaal bestemd is om vast verblijf te houden in het te stichten rendez-vous en vier bij den G.G. zullen resideeren of voor missies buiten diens residentie kunnen worden gebruikt. Eén van deze vier moet „eymant” zijn, die ,best in de policie en zaken van regten ervaren mocht wesen, om meteen ook het fiscaals-ambt te bedienen, en in alle zaken, de justitie concerneerende, by het aannemen van eenige informatiën, de generale politie en regeering concerneerende, geëmployeerd en tot alle plaatsen, waar zulks noodig mocht wezen, gecommitteerd en afgezonderd te worden". Ook bij deze permanente regeerings-commissie in algemeenen dienst liggen dus alle machten, ongescheiden, in één hand. Doch terwijl het presidiaat en het fiscalaat gescheiden blijven treedt de Raad-advocaat-fiscaal, in zoover hij zich bezig houdt met justitiëele vaken, nu tegelijk op als aanklager en als rechter. Dit is geen gelukkige regeling; men is dan ook genoodzaakt er later op terug te komen, eerst door hem uit den Raad te doen treden, later door hem er weer in te brengen, doch slechts met een adviseerende stem. De vier overige Raden zullen de vice-gouverneurs-directeurs van de Molukken, Coromandel, Amboina en Banda zijn. Deze laatste bepaling houdt nauw verband met den in art. 7 herhaalden last, om op alle forten, kantoren en schepen ,locale rechtscolleges” in te stellen, aan welke nu zoowel de civiele als de crimineele rechtspraak in hunne ressorten wordt opgedragen. Voorzitter dezer locale colleges wordt de hoogste dienaar in elk ressort; in de Molukken, op Amboina, op Banda, in Coromandel dus de vice-Gouverneur. Men beschikt nu vermoedelijk op alle nederzettingen over voldoende daar gestationneerde schippers en kooplieden, om niet langer, voor de behandeling der crimineele zaken, afhankelijk te moeten zijn van binnenloopende schepen; door dezen maatregel meent men blijkbaar voor de belangrijkste raden rechtsverstandige presidenten te krijgen; en zoo durft men het thans aan, den localen justitieraden de volle rechtsmacht, de berechting van alle, zoowel civiele als crimineele zaken, de halszaken incluis, toe te vertrouwen. Daardoor smelten de oorspronkelijke breede 
raad van zessen en de smalle raad van vieren ongemerkt ineen; al zal men den regel om de crimineele zaken met een grooter vast minimum-aantal rechters te behandelen dan de civiele zaken, in de practijk wel hebben vastgehouden. De reden van deze organisatie wordt in art. 8 duidelijk uitgesproken; de locale justitieraden zijn noodzakelijk, omdat de G.G. en de Raden van Indië, die nog altoos als een mobiel college worden beschouwd, ,in alle plaatsen niet present kunnen wezen". Deze omstandigheid bepaalt hun karakter. De locale justitieraden zijn, oorspronkelijk, ten opzichte van den met de opperste rechtsmacht in het handelsrijk bekleede G.G. en Rade, geen mindere, doch plaatsvervangende raden, die alleen functionneeren „bij absentie” van den G.G. en Rade van Indië, maar die, indien zij functionneeren, volkomen dezelfde volle rechtsmacht bezitten, die de G.G. en Rade, ter plaatse vertoevend, zouden kunnen uitoefenen.

Beschouwt men de in Coens instructie voorgeschreven rechterlijke organisatie in abstracto, dan rijzen er verschillende vragen:

1e. bracht deze regeling mede dat ook in het rendez-vous een op denzelfden voet als in de overige nederzettingen geschoeide justitieraad moest bestaan?

2e. heeft zulk een raad te Jacatra, en later te Batavia ook werkelijk bestaan?

3e. wat geschiedde er met deze justitieraden, wanneer de G.G. en Rade zich hun standplaats voor korter of langer tijd tot residentie koos?

Het antwoord op de eerste vraag kan slechts bevestigend luiden; het voorschrift een rechtscollege voor de behandeling van zoowel civiele als crimineele zaken in alle kantoren, schepen enz. op te richten was imperatief en duldde geen uitzondering. Dat het kantoor te Jacatra tot rendez-vous werd gekozen en zich spoedig tot hoofdplaats en vaste residentie der Hooge Regeering ontwikkelde, doet daaraan niets af. Moeilijker is het een bevredigend antwoord op de tweede vraag te geven. Heeren XVII, van wie wij mogen aannemen, dat zij de bedoeling van hun eigen instructie zullen hebben begrepen, en die op hun beurt mochten aannemen, dat Coen die instructie naar de letter zou hebben uitgevoerd, verkeerden in de meening, dat zulk een lokale raad ook in Jacatra inderdaad bestond. Naar aanleiding van Coen's verslag van 31 Juli 1620 over den groei van Jacatra uitweidend over de toekomstige organisatie der stad, schrijven zij hun Landvoogd op 4 Maart 1621 ten aanzien van de in te stellen Schepenbank: ,indien hem iemant bij voornoemde Schepenen vint beswaert, 
die sal daervan vermogen te provoceeren als nae rechten; in absentie van den Gouverneur-Generaal en de Raden van Indiën aan den Gouverneur van de stadt ende 't casteel ende sijne raden", .... die by uytterste ressort by absentie als voren, met advijs van den advocaatfiscaal, daarvan gehouden sullen wesen kennis te nemen. Een logische toepassing van hun organisatie; want by afwezigheid van de Hooge Regeering waren, gelijk wij zagen, alle locale justitieraden, dus ook die van Jacatra, plaatsvervangende colleges, die dus, evenals de G.G. en Rade zelf, in uwtterste ressort, d.w.z. in hoogste instantie, beslisten. Dr. F. W. Stapel, in zijn voor de materie der rechterlijke organisatie grondleggende Bïdragen tot de Geschiedenis der Rechtspraak bij de Vereenigde Oost-Indische Compagnie ${ }^{1}$ ), meent echter, dat Bewindhebbers zich vergisten: „Uit deze bewoordingen blijkt, dat Heeren XVII van meening waren, dat behalve de Hooge Regeering, bestaande uit G.G. en Rade, te Batavia ook nog een plaatselijke gouvèrneur met een raad zetelde, belast met het bestuur over de stad en de Ommelanden. Zooals men weet, was dit niet het geval, maar was de G.G., behalve met de algemeene leiding, ook belast met het rechtstreeksch bestuur over Batavia en het voormalig Koninkrijk Jacatra". Is deze critiek juist? Ik betwijfel het en meen, dat Heeren XVII het bij 't rechte eind hebben gehad, althans indien men in 't oog houdt, dat zij niet van de stad en ommelanden, maar van de stad ende 't casteel ${ }^{2}$ ) spreken. Daarop gelet stemt de werkelijk op dit oogenblik bestaande toestand met de voorstelling van Heeren XVII overeen. Dat er onder Coen's eerste Generalaat een afzonderlijke Gouverneur van Jacatra bestond staat onomstootelijk vast; hij wordt uitdrukkelijk genoemd in Coen's ordonnantie van 20 April $1622^{3}$ ), houdende voorschriften nopens 't verhandelen, regeeren en opvoeden van slaven, van welke het toezicht op de naleving wordt opgedragen aan de goede zorg o.a. van den ,"Gouverneur deses coninckrijcx Jacatra, en alle andere Gouverneurs" ${ }^{4}$ ). Uit de opdracht zelf volgt,

1) Vg1. Bijdragen, enz., D1. 89, p. 41 e.v.; D1. 90, p. 89 e.v.

2) Weliswaar was de resolutie van 29 Maart 1620, bij welke Coen, in weerslag op het 27 Maart d.a.v. ingekomen bericht omtrent het accoord van $17 \mathrm{Juli}$ 1619 , een baljuw benoemt over het geheele gebied van het voormalig Koninkrijk Jacatra, aan Heeren XVII, bij het schrijven van hun brief, bekend; doch het zuiver politieke oogmerk van deze resolutie was hen natuurlijk niet ontgaan en zij begrepen opperbest dat er van eenige werkelijke bestuursoefening in deze wildernis voorloopig nog geen sprake zou kunnen zijn; zeer terecht gebruikten zij daarom den met den werkelijken toestand strookende titulatuur.

3) Vg1. Van der Chïs: Placcaatboek, I, p. 96/99.

4) Dat deze Gouverneur thans niet langer, zooals in de brief van Heeren XVII 
dat dit gouverneurschap geen bloote titel was, dat de gouverneur, als zoodanig, zekere van de Hooge Regeering onderscheiden bevoegdheid in zijn ressort bezat. Deze afzonderlijke Gouverneur van Jacatra (Batavia) is overigens geenszins een ephemere verschijning; de positie blijft ook na Coen's eerste ambtsperiode bestaan. Dit blijkt uit De Carpentier's resolutie van $16 \mathrm{Juni} / 23$ Aug. 1625, waarin (art. 3) de jaarlijksche benoeming van schepenen van Batavia bij afwezigheid van den Generael wordt opgedragen aan den Gouverneur vant Casteel ende Hare Edts. achtbare Raden ${ }^{1}$ ). Uit deze plaats blijkt bovendien, dat Heeren XVII ook hierin gelijk hadden, dat deze ,gewestelijke” Gouverneur, evenals zijne collega's elders, wel degelijk een eigen raad bezat, al wordt ook hier, bij de later te bespreken ${ }^{2}$ ) onmogelijkheid, eigenlijke colleges met vast personeel in stand te houden, van „raden”, in plaats van ,raad” gesproken. De Gouverneur van Jacatra (Batavia) oefende zijn bevoegdheid dus, evenals zijn collega's elders, uit met medewerking van dezen raad, als „G. en Rade”. Van welken aard de bevoegdheid van dit college was? Heeren XVII kennen het, in hun aangehaald schrijven van 4 Maart 1621, rechterlijke bevoegdheid toe. Doch men wachte zich „G. en Rade" te Batavia of elders als een zuiver justitiëel college te beschouwen. Evenals G.G. en Rade (de Hooge Regeering) waren G. en Rade, de locale regeeringen te Batavia en elders, krachtens het beginsel der plena potestas tegelijk èn besturende èn wetgevende èn rechterlijke colleges. Wie bekleedde nu, in Coen's tijd, dit Gouverneursambt? Als men het stelsel van Coen's instructie logisch doordenkt, kan men 't wel gissen! De G.G. en Rade waren gedacht als een mobiel college; de locale gouverneurs en hun justitieraden functioneerden alleen wanneer het Hoogste Rechtscollege niet ter plaatse was.

Voor 't geval dat de Landvoogd en zijn Raden afwezig waren, moest er dus ook in het rendez-vous een gouverneur zijn. Deze gouverneur kon natuurlijk geen lageren rang hebben dan de opperhoofden der vier andere hoofd-kantoren en kwartieren, de Molukken, Coromandel, Amboina, en Banda. Deze nu waren, sedert 1618, Raden van Indië. Ook de gouverneur van Jacatra moest dus Raad van Indië zijn. Welke Edeleer was daartoe beschikbaar? De G.G. moest zijn bewegingsvrijheid houden; daartoe was de geheele organisatie

als gouverneur van de stad en 't casteel wordt aangeduid, is het gevolg van de nu effectief geworden resolutie van 29 Maart 1620; vgl. noot 1.

1) Vgl. Van der Chijs: Placcaatboek, I, p. 127.

2) Vgl. pp. 12, 13, 23, 27. 
opgezet; trouwens alleen bij zijn afwezigheid was het plaatsvervangend optreden van een lokalen gouverneur ook op Jacatra noodig. Ook drie van de vier andere in den regel bij den Landvoogd resideerende Raden moesten, voor het geval hun, krachtens art. 3 van de Instructie van 1617, eenige missie buiten het rendez-vous mocht worden opgedragen, beschikbaar blijven, en konden dit ambt dus niet bekleeden. De eenige Raad van Indië die, krachtens zijn positie, sedentair was in het rendez-vous, en daar moest achterblijven, ook wanneer G.G. en de vier andere Raden ambtshalve elders vertoefden, was de Directeur-Generaal, op dit oogenblik De Carpentier. Wanneer het stelsel der Instructie dus juist werd toegepast, kon, op dit oogenblik, alleen De Carpentier Gouverneur van Jacatra zijn.

En werkelijk, het blijkt dat De Carpentier deze functie inderdaad bekieed heeft: in het Rijksarchief bevinden zich eenige brieven aan De Carpentier in 1622 en het begin van 1623 (vóór Coen's vertrek naar patria) door Compagniesdienaren gericht, waarin deze wordt aangeduid als: Raad van Indië, Directeur-Generaal en Gouverneur van 't Kasteel Batavia ${ }^{1}$ ).

Wij hebben gezien, dat Coen, 27 April 1618, was opgetreden als president van het locale rechtscollege te Jacatra. Aanvankelijk wel, evenals de locale justitieraad te Bantam, een alleen tot de afdoening van civiele zaken bevoegde mindere raad, was het later ${ }^{2}$ ) ook bevoegd geworden tot berechting van crimineele zaken. De Jacatrasche rechtbank was dus, toen Coen zijn benoeming tot Landvoogd ontving, reeds een college in den zin van art. 7 zijner Instructie.

Dit college blijft, steeds onder Coen's leiding, aan 't werk, tot vóór enkele dagen na Dale's verschijnen in Straat Soenda. Wat is er sedert Coen's vertrek naar de Molukken met den Jacatraschen justitieraad gebeurd? Vermoedelijk heeft hij, onder presidium van Coen's plaatsvervanger Van den Broecke, zoo goed en kwaad het ging, voortbestaan.

En wat gebeurt er sedert Coen's terugkeer als Landvoogd?

Wat er, krachtens de Instructie, behóórt te gebeuren, is niet in 't minst twijfelachtig. De G.G. en Rade, in het rendez-vous weergekeerd, behooren nu de rechtspraak zelf te gaan uitoefenen. En dit gebeurt inderdaad ook. Reeds op 27 Juni, binnen een maand na zijn terugkeer, houdt de Landvoogd met zijn presente raden zijn eerste

1) Ik dank deze wetenschap aan de vriendelijke mededeeling van $\mathrm{Dr}$. W. Th. Coolhaas, die deze stukken in den loop zijner onderzoekingen heeft aangetroffen.

2) Vgl. Besch., IV, p. $225 / 6$. 
rechtszitting; de tweede wordt besteed om den lamlendigen fortverdedigers een flinken duw te geven. Voor het oogenblik is het college nog incompleet; er zijn slechts twee edeleers present en het college wordt daarom met den afgetreden landvoogd Reaal en een paar hooge dienaren, een commandeur en een opperkoopman, aangevuld. Maar allengs komen ook de overige raden aan: 14 September zit de compleete Hooge Regeering onder Coen's presidium voor het eerst als Jacatra's rechtbank; de rechterlijke organisatie van 1617 is dus nu volgens ,model” ingevoerd. Het verdient opmerking dat, in de nu volgende zittingen, de Hooge Regeering niet alleen de crimineele, maar ook de civiele zaken behandelt. Zelfs de ,aldercivielste”: de eerste rechtszitting van het complete Hooge College is ,gewijd" aan de behandeling van een vechtpartij tusschen twee dronken tamboers over een ,,silvere tabacgpijpje”; de schuldige, luidt het vonnis, zal een maand voor den prins werken, en, bovendien, den beschadigde drie rèalen ,,voor zijn smerte”, den barbier twee ditto voor zijn meestersloon betalen. Wat is er (wij herhalen de vraag) onder deze bedrijven met den ouden, localen justitieraad van Jacatra gebeurd? Formeel ontbonden is hij niet; dit kon ook niet, omdat hij geen eigenliik college met vast personeel vormde. Want hoewel, zooals blijkt uii Wittert's instructie, dergelijke locale justitieraden aanvankelijk alle bedoeld waren als vaste colleges met een vast personeel: het sterke verloop, door sterfte en uitzending van employés, maakte het vrijwel ondoenlijk, een vaste bezetting te handhaven; men moest zich meestal behelpen met het committeeren, als rechtsluiden, van de menschen, die toevallig ter plaatse aanwezig waren; de ,raad” verliep meestal in een aantal, voor een of eenige zittingen benoemde, ,raden”, omdat hij geen eigenlijk college met vast personeel vormde. Ontbinding zou overigens niet practisch geweest zijn, daar hij bij een onvoorziene nieuwe afwezigheid der Hooge Regeering aanstonds weer als plaatsvervangende raad zou moeten invallen. Hij houdt dus eenvoudig op te fungeeren, omdat hij niet weer bijeengeroepen wordt.

Intusschen duren de model-rechtszittingen van G.G. en Rade niet lang. Binnen een maand geeft het Hooge College er de brui van; 9 October 1619 wordt voor het eerst een sententie uitgesproken door .,de gecommiteerde raden vanwege d'E. heer Generaal," onder presidium van De Carpentier. Wat is er geschied? Een ,nieuwe figuur”?

Wat er geschied is, laat zich gemakkelijk raden. Men leefde omstreeks het eind van 1619 te Jacatra in een belangrijken, drukken tijd; de Hooge Regeering had de handen vol met gewichtig werk. 
Was het verantwoord, deze leidende mannen hun tijd te laten verdoen aan beuzelingen? Maar nog minder verantwoord ware het geweest de opperste rechtsmacht over het handelsrijk, die hier met de rechtsmacht over Jacatra samenviel, uit handen te geven; want dat zou een schending beduid hebben van de door den Souverein der Republiek en Heeren XVII aan de Hooge Regeering gedelegeerde plena potestas, van welke de klem van de Regeering van den Nederlandschen Staat in Indië afhing. Gelukkig stond men niet voor een dilemma. Er was een tweetal zeer bruikbare uitwegen uit de moeilijkheden.

De eerste uitweg lag het meest voor den voet. Het feit, dat bij de Hooge Regeering de plena potestas berustte, maakte een goede werkverdeeling dringend noodzakelijk. Zulk een werkverdeeling lag reeds opgesloten in het voorschrift, dat voor de verschillende ordinaris Raadsplaatsen bepaalde specialisten moesten worden gekozen. Het College wees dus voor de verschillende onderdeelen van de Regeeringstaak een commissaris of commissarissen uit zijn midden aan. Maar deze konden natuurlijk nooit zoo talrijk zijn, dat zij-alleen een voldoend bezet rechtscollege kon vormen. Men moest dus hulpkrachten buiten het college assumeeren. In dit geval werd als commissaris uit de Hooge Regeering benoemd De Carpentier. Natuurlijk. Want hij, de in elk geval in het rendez-vous achterblijvende directeur-generaal, was de man, die als Gouverneur van Jacatra bij afwezigheid van de Hooge Regeering den localen (sedert 28 Maart 1620 gewestelijken) justitieraad zou moeten voorzitten; door deze commissie bleef hij, op justitiëel gebied, in goede training. En even natuurlijk, dat de Hooge Regeering tot zijn hulpkracht de krachten koos, waarmede hij den gewestelijken raad zou moeten vormen, indien G.G. en Rade eens op reis gingen. Dezelfde krachten, niet dezelfde personen. Want het voortdurend va et vient maakte nog steeds het bestaan van een eigenlijk college, met een vast personeel, onmogelijk. Maar personen van dezelfde qualiteit, als waaruit de locale raden van Batavia en Bantam plachten te worden samengesteld. Is de justiciabele een niet-militair, dan assumeert hij zich, behalve den onvermijdelijken koopman en schipper (resp. opperkoopman en commandeur), zoo mogelijk drie niet-militaire suppoosten; is het een militair, dan drie militaire bijzitters. Op den duur committeert men altoos èn een paar militaire èn een paar niet-militaire suppoosten van 't fort, wat ook met het oog op de z.g. gemengde zaken (zie infra), waarin militairen en niet-militairen gemoeid waren, practisch was. Wat men 
als Gecommitteerde Raden aanduidt komt dus neer op een gecombineerde logeraad en krijgsraad onder leiding van een gedelegeerd lid van den Raad van Indië. Dit beteekent echter geenszins, dat deze raden nu een zelfstandig rechtsprekend college vormen. Hun functie wordt het best verduidelijkt door de resolutie van G.G. en Rade van 8 Aug. 1620, waarbij ,worden gecommitteerd als ordinariscommissarissen" een 8 tal personen, daeruyt telkens drie of vier bij den advocaat fiscaal Martinus Sonck present sullen wesen, omme op alle voorvallende occasiën ten overstaan van deselvige goede informatie te mogen nemen” ${ }^{1}$ ). Deze ,personen” zijn dus een soort hulpofficieren van justitie. Op overeenkomstige wijze worden er ook (veelal dezelfde) personen gecommitteerd, om ten overstaan van het gedelegeerd lid van de Hooge Regeering als hulp-rechters te fungeeren. Doch in wezen doen deze gecommitteerde raden niets anders, dan de zaak in staat van wijzen brengen ${ }^{2}$ ). Daartoe formuleerden ze een concept- of voorloopig vonnis, dat echter eerst uitgesproken wordt, indien de Hooge Regeering zich daarmee vereenigt. De wijze waarop deze approbatie normaliter verkregen wordt staat niet vast. Vermoedelijk zal zij in civiele zaken geacht zijn geworden stilzwijgend te zijn verleend, wanneer het de raden voorzittend gedelegeerd lid der Hooge Regeering geen bezwaar maakte. Doch in crimineele zaken moet de goedkeuring van het vonnis opzettelijk vooraf worden gevraagd ${ }^{3}$ ). Daar de voorzitter der raden en (althans geruimen tijd) de advocaat-fiscaal leden zijn van het Hooge College, is dit in staat zich over de mérites eener zaak grondig te doen voorlichten. Doch zoo vaak de Hooge Regeering het met het advies van Gecommitteerde Raden niet eens is, of dit om andere reden wenschelijk oordeelt ${ }^{4}$ ), is zij het, de draagster van het hoogste rechterlijk gezag in Compagnies handelsrijk, die de ,,sententie definitive" velt ${ }^{5}$ ), zij ook kan beslissen of er rechtsingang zal worden verleend ${ }^{6}$ ), wanneer een zaak zal worden behandeld ${ }^{7}$ ), of er reden is tot heropening van de instructie ${ }^{8}$ ), dan

1) Vgl. Besch., III, p. 626/7.

2) Vgl. Besch., III, p. 820 .

3) Vgl. Besch. In crimineele zaken, geen halszaken zijnde, is althans na 16 Juni 1621 alleen approbatie noodig voor de uitvoering van de sententie; vgl. Van der Chijs: Placcaatboek, I, p. 125; doodvonnissen in halszaken behoeven approbatie voor ze worden uitgesproken; vgl. Besch., III, p. 232; IV, p. 198.

4) Vgl. Besch., IV, p. 219.

5) Vgl. Besch., III, p. 631 .

6) Vgl. Besch.. IV, p. 210.

7) Vgl. Besch., III, p. 628 .

s) Vgl. Besch., III, p. 631. 
wel of een zaak voorloopig ${ }^{1}$ ) of voor goed zal blijven rusten ${ }^{2}$ ). Ook vermag de Hooge Regeering de berechting van een of andere belangrijke zaak aan zich te houden. In een woord, het is de Hooge Regeering, die de justitie ex plena potestate beleidt.

Het gebruik maken, in het rechtswerk, van Gecommitteerde Raden beduidt overigens niet, dat de overige leden van de Hooge Regeering zich nu van de hun opgedragen rechtspraak niets meer aantrekken; zijn ze vrij, dan komen ze vaak nog een belangrijke zaak medeberechten. Maar noodzakelijk is hun aanwezigheid niet meer: onder leiding van De Carpentier is de regelmatige voortgang van de rechtspraak nu, ondanks de drukke andere besognes van het Hooge College, voldoende verzekerd.

De Gecommitteerde Raden zijn dus in wezen niets anders, dan de oude locale justitieraad van Jacatra, die echter voor den duur van de residentie van de Hooge Regeering in het rendez-vous, niet als zelfstandige, plaatsvervangende raad, maar, in commissie van het hic en nunc alleen bevoegde Opperste Rechtscollege, G.G. en Rade, als deszelfs onzelfstandig hulporgaan optreedt.

Door deze oplossing bleef echter de justitie in het geheele uitgestrekte rechtsgebied van het voormalig Koninkrijk Jacatra op het Kasteel gecentraliseerd. Dit kon bij de toenemende bevolking vóór het Kasteel op den duur zoo niet blijven. Er bestond ecter een andere en betere weg om de overbelasting van de Hooge Regeering met justitiëele zaken te remediëeren: decentralisatie. Het betreden van dien weg werd mogelijk gemaakt door de reeds in patria met Heeren XVII in algemeene trekken besproken politieke organisatie van het gebied, die, bij de innige verbinding van bestuur en rechtspraak, als van zelf de overdracht der lagere justitie aan stedelijke en landelijke ${ }^{3}$ ) organen meebracht. Het is klaarblijkelijk, dat Coen bij het scheppen van deze organisatie de instellingen van zijn vaderland West-Friesland voor oogen hebben gestaan ${ }^{4}$ ).

Als eerste stap op dien weg wordt bij resolutie van 24 Juni 1620 voor de stad Jacatra een Schepenbank ingesteld, bij welke de baljuw van stad en land Jacatra als officier van justitie optreedt. Deze Schepenbank is een mindere raad in den zuiveren zin des woords;

1) Vg1. Besch., IV, p. 232.

2) Vgl. Besch., III, p. 821 .

3) Te weten, Heemraden.

4) De Heemraden waren, in tegenstelling met Holland, in West-Friesland tevens rechtscolleges, bevoegd tot berechting van civiele zaken.

D1. 103. 
wel is van sommige van haar vonnissen appèl mogelijk, maar zij spreekt zelfstandig recht. Aan de Schepenbank wordt toevertrouwd de administratie van ,alle justitie" doch alleen in ,civile saecken”. Daaruit volgt dat de berechting van ,crimineele saecken” voorloopig bij de Hooge Regeering bleef, die ze, als tot dusver, op de bovenomschreven wijze, door Gecommitteerde Raden deed voorbehandelen. Maar welke personen vallen onder de jurisdictie van de Schepenbank?

In beginsel: alle burgers of vrijlieden der stad. De Nederlanders waren zeer gehecht aan het voorrecht, door hun soortgenooten te worden berecht; de vrijburger door een Schepenbank; de schepeling door een scheepsraad; de militair door een krijgsraad, enz. Door de instelling van de Schepenbank verwierven de burgers van Jacatra nu dit zoozeer gewaardeerde privilege; makten zij zich op het gebied der stad aan een misbruyck schuldig, dan werden zij door den officier der stad, den baljuw, gevat; geschiedde dit in of buiten 't Kasteel, dan door den officier van het fort, den advocaat-fiscaal, die hen aan den stedelijken rechter overleverde. Dit was dus eenvoudig genoeg. Doch er rees een moeilijkheid, wanneer een burger met een niet-burger slaags of op eenigerlei andere wijze in een rechtzaak betrokken raakte; waar en voor welken rechtbank moesten de delinquenten dan terechtstaan? Want zoowel de vrijburger als de militair kon aanspraak maken op het privilege door hun eigen, ,zoogenaamd natuurlijken" rechter berecht te worden. Hier was dus een nadere regeling noodig. Deze regeling, neergelegd in de bekende resolutie van 15 Aug. 1620, kwam hierop neer, dat voor gemengde zaken gemengde rechtbanken werden gevormd; wanneer b.v. een soldaat uit het fort betrokken raakte bij een vechtpartij met een vrijburger in de stad, dan moest hij terechtstaan voor de Schepenbank, samengesteld uit 5 schepenen en twee leden van den krijgsraad van het fort; geschiedde dit met een niet-militair suppoost van het fort, dan werd de schepenbank aangevuld met twee ordinaris-commissarissen van het fort; had een vrijburger hetzelfde ongeluk met zulk een suppoost in het fort, dan stond hij terecht voor de ordinaris commissarissen van 't fort, versterkt met twee schepenen enz., ,alles ten eynde de jurisdictie ende authoriteyt van beyde de gerechtsofficieren ten wederzyden blyven in vigeur, ende alle misverstanden ende confusiën, daerover te ontstaen, (worden) verhoet". Waarop de resolutie vervolgt :

„Ende gemerkt de schepenen van den stadt alreede vercoren ende hare gerichtsampt exerceerende zijn in vougen, dat binnen 't fort ten 
voors. eynde de commissarissen oock dienen gestelt, soo sijn tot commissarissen ende ordinaris luyden van den gerechtte in 't fort by den Ed. Heer Gouverneur-Generaal en synen Raedt genomineert ende gecomiteert dese naervolgende personen" (volgen acht namen, zoo van militaire als niet-militaire suppoosten van 't Kasteel).

Welke is nu de beteekenis van de instelling van dit college in de geschiedenis van de rechterlijke organisatie in Nederlandsch-Indië? De opvattingen daaromtrent loopen sterk uiteen. Volgens Colenbrander: nihil; het ,college” van Gecommitteerde Raden krijgt, volgens hem, op 15 Aug. 1620 slechts een nieuwen naam ${ }^{1}$ ). Volgens Stapel, die van een mijlpaal: „nog belangrijker” (dan de instelling van den Schepenbank) ,was de resolutie daaraanvolgende, die een rechtsprekend college instelde. De genoemde resolutie stelt dit lichaam niet slechts in, maar omschrijft ook omstandig zijn bevoegdheden, en, in verband daarmede, tevens die van de Schepenbank ${ }^{2}$ ). Ik kan mij met geen van beide opvattingen geheel vereenigen. Dat, gelijk Colenbrander meent, het 15 Aug. 1620 ingestelde college volkomen identiek zou zijn met de Gecommitteerde Raden, schijnt uitgesloten. Het Opperste Rechtscollege, gelijk wij zagen, was bevoegd, om berechting van belangrijke zaken aan zich te houden, het maakte daarvan ook soms gebruik, in welk geval het advies van Gecommitteerde Raden inwon. Maar soms ook laat het belangrijke zaken, onder zijn approbatie, berechten door speciaal voor die zaken benoemde Gecommitteerde Raden in dubbelen getale. Anders gezegd: men moet onderscheiden tusschen breede en smalle Gecommitteerde Raden. De eerstgenoemde zijn nu in het nieuwe college van 15 Aug. niet overgegaan of opgelost. Ware dit zoo, dan zouden immers alle sententies van Gecommitteerde Raden na 15 Aug. de onderteekening moeten dragen van, behalve den president ${ }^{3}$ ), minstens $5^{4}$ ) en hoogstens alle 8 ordinaris luyden van den gerechte, leden van dit college. Alle sententies na 15 Aug. dragen echter deze onderteekening niet.

Reeds de twee vonnissen van Gecommitteerde Raden van $25^{5}$ ) en $26^{6}$ ) Aug. 1620 worden gewezen door een rechtbank, waarin,

1) Vgi. Besch., IV, p. x.

2) Vgl. Stapel: Bijdragen tot de rèchtspraak, etc., I. p. 89.

3) Vgl. Resolutie van 15 Aug. 1620: „In dit college zal presideren een van de Raden van Indiën"; president was De Carpentier.

4) Vgl Resolutie van 15 Aug. 1620: Sullen oock de luyden van den gerechte in college niet minder mogen besoigneeren als met vijf personen, maer wel met meerdere".

5) Vgl. Besch., III, p. 628.

6) Vgl. Besch., IV, p. 210. 
naast den president, 7 der op 15 Aug. benoemden (de ,cappiteyn van de prauwen", J. Gerritsz, ontbreekt) en 8 buitenstaanders, waaronder een tweede Raad van Indië, J. Dedel, zitten: de rechtspraak der breede Gecommitteerde Raden blijft dus, ook na de instelling van het nieuwe college, en daarvan onafhankelijk, voortbestaan.

Het andere punt, dat Colenbrander bij zijne identificatie over het hoofd heeft gezien is, dat de eigenaardigheid van Gecommitteerde Raden juist is: dat zij géén college vormen. Uit de groep van personen, die men naar den eisch van 't oogenblik als rechtsluiden pleegt te committeeren, poogt eerst de resolutie van 15 Aug. 1620 een vast college, met een vast personeel en vaste zittingsdagen, te formeeren; door deze resolutie krijgt dit college een publiekrechterlijke existentie; en daarin ligt, naar Stapel zeer juist ziet, haar belang. Dat deze resolutie echter ook belangrijk zou zijn, omdat zij, zooals Stapel het uitdrukt ,dit lichaam niet slechts instelt, maar ook zijn bevoegdheid omstandig beschrijft" (ik cursiveer), kan ik niet toegeven. Ik vrees zelfs, dat Stapel, bij deze uitspraak, onbewust eenigszins onder den invloed is geweest van het opschrift, dat Van der Chijs in zijn Plakkaatboek boven deze resolutie eeft doen drukken: „Provisioneele instructie voor d'ordinaris luyden van den Gerechte van 't Casteel Vaststelling hunner jurisdictie.... (ik cursiveer). Van der Chijs was blijkbaar met de, uit de sententies van Gecommitteerde Raden blijkende, voorgeschiedenis weinig bekend, en is zoo begrijpelijker wijze tot een overschatting van de beteekenis van de resolutie verleid. In werkelijkheid bevat de resolutie maar zeer weinig, dat als omstandige omschrijving van de bevoegdheid van het nieuwe college kan worden opgevat. En dit behoefde ook niet. Want, strict genomen, had het nieuwe college, evenmin als Gecommitteerde Raden, een eigen jurișdictie; zij behandelde de haar opgedragen zaken, welke behoorden tot de jurisdictie van de Hooge Regeering. Deze jurisdictie nu was door de resolutie van 1 Juli 1620 , waarbij een Schepenbank was ingesteld, zoodanig beperkt, dat de berechting van de civiele zaken der vrijburgers voortaan niet meer tot de jurisdictie der Hooge Regeering behooren zou, en dus ook niet aan het nieuwe college, dat de ordinaris Gecommitteerde Raden verving, kon worden toevertrouwd. Het is dus niet zoo, als Van Kan p. 26 van zijn besproken studie stelt: „nu nevens de bestaande rechtbank van schepenen een tweede rechtscollege van eenigermate hoogeren stand was opgericht", maar juist omgekeerd: ,nu onder het bestaande Opperste Rechtscollege, een mindere Rechtbank, de Schepenbank, was ingesteld”. 
Maar waarom werd het, tengevolge van die instelling, opeens zoo dringend noodig, om uit de commissarissen of Gecommitteerde Raden van dat Opperste Rechtscollege ook een nieuw college voor het Kasteel in te stellen? De noodzakelijkheid daartoe toch ligt niet voor de hand; de berechting, zoowel van de civiele als van de crimineele zaken, voorbereid door de Gecommitteerde Raden, door het, volgens de organieke regeling der Instructie van 1617 voor het ressort Jacatra bij zijn aanwezigheid alleen competente rechtscollege de Hooge Regeering, liep toch regelmatig; indien men nu een Schepenbank wilde instellen, zou het toch, naar het schijnt, voldoende zijn geweest, om haar ,jurisdictie en authoriteyt"vast te stellen; omdat daaruit automatisch volgde, welke jurisdictie en authoriteyt de Hooge Regeering (Gecommitteerde Raden) had afgestaan. Waarom dan, en met zooveel haast, een nieuw college ingesteld? En dat er haast was bij die instelling blijkt ten duidelijkste uit de woorden van de reeds aangehaalde instellings-resolutie: Ende gemerckt de Schepenen van den stadt alreede verkoren ende haeren gerichtsampt exerceerende sijn, in vougen dat binnen 't fort ten voors. eynde de commissarissen oock dienen gestelt". Er is dus, voor de stellers der resolutie, een natuurlijk en noodzakelijk verband geweest tusschen de benoeming van de leden van de Schepenbank en de benoeming van de leden van het nieuwe college, dat ons, op 't eerste gezicht, ontgaat. Welk is dit verband geweest? De sleutel tot oplossing van dit probleem ligt in de woorden ,ten voors. eynde”. Het bedoelde eennde is ,,voorseyd” in de voorafgaande zinsnede, die zegt, dat de in de resolutie voorafgaande regelingen zijn gemaakt ,alles ten eynde de juridictie ende authoriteyt van beyde de gerechten ende gerechtsofficieren ter wederzyden blyven in vigeur, en alle misverstanden, daerover te ontstaen, worden verhoet". De in de resolutie voorafgaande regelingen, voor zooveel zij de beide gerechten betreffen, bepalen de competente rechters $1^{\circ}$ in de simpele $2^{\circ}$ in de gemengde zaken. Voor de bepaling van de rechters in de simpele zaken van het Fort, was de instelling van een nieuw college en de benoeming van de leden daarvan, volkomen overbodig ; misverstand en confusie daaaromtrent was ondenkbaar; een verwijzing naar de Hooge Regeering (Gecommitteerde Raden) zou hebben volstaan. Het natuurlijk en noodzakelijk verband ligt in de noodzakelijkheid, om de samenstelling van de rechtbanken voor gemengde zaken te regelen. De colleges werden, in den regel, bijeengeroepen door hun president. Doch de voorgeschreven aanvulling dier colleges bij behandeling van gemengde gevallen, moest, volgens de resolutie van 15 Aug., niet door de 
presidenten, maar door de officieren van Justitie - den baljuw en den advocaat-fiscaal - van beide colleges bezorgd worden ${ }^{1}$ ). Dit was trouwens logisch. $\mathrm{Z}_{\mathrm{ij}}$ toch, de officieren, wisten vóór de rechters, of een zaak al dan niet een gemengde zaak was, en hoe zij gemengd was.

Wanneer nu de baljuw, teneinde een gemengde zaak te doen berechten, twee krijgsraden of twee burgerlijke rechters van het Kasteel in de Schepenbank, of, met hetzelfde doel de advocaat-fiscaal twee schepenen bij de rechters van het Fort moesten bijroepen, moesten zij natuurlijk weten tot welke personen zij zich dienden te wenden; d.w.z. wie er rechter waren in het Kasteel resp. de Stad. Voor de stad stond zulks reeds vast; dáár was een college met vast personeel, de namen der 5 schepenen waren bekend, en de advocaat- fiscaal had uit hen maar te kiezen. De baljuw was echter niet zoo gelukkig; want het Kasteel, was, behalve de Hooge Regeering, geen rechtscollege rijk; dat de baljuw, wanneer er een bekkensnijderij tusschen een soldaat en een vrijburger te berechten viel, daartoe twee leden van 't Opperste Rechtscollege, Coen en De Carpentier b.v., tot bijzitters in de Schepenbank zout mogen ontbieden was natuurlijk uitgesloten; en de Gecommitteerde Raden vormden geen college noch een vaste commissie, maar werden voor verschillende zaken uit verschillende personen gekozen; de baljuw kon dus niet weten wie hij, als bijzitters, uit het Kasteel zou kunnen kiezen. Om dit te weten te komen, zou hij zich bij elk voorkomend geval hebben moeten wenden tot de Hooge Regeering of haar voorzitter, den Landvoogd, om aanwijzing van bijzitters, wat natuurlijk uiterst lastig en tijdroovend zou zijn geweest. Aan deze moeilijkheid bedoelde de resolutie van 15 Augustus een einde te maken. Door de omvorming van de individuëele Gecommitteerde Raden tot een college en de benoeming van een zevental ${ }^{2}$ ) vaste ordinaris commissarissen voor een vasten tijd, werd een reservoir gevormd, waartiit de baljuw, naar het geval lag, maar voor 't kiezen had.

Van 15 Augustus 1620 af bestaan er dus in 't Kasteel van Jacatra twee ,colleges”, die zich, in onderling verband, met de rechtspraak bezig houden; 1e het college van G.G. en Rade, 2e het college van

1) „mits dat de bailliu gehouden sal sijn daerby te roepen twee van den crijchsraedt ende (ofte, verbetert Stapel,) ordinaris commissarissen ende gerechtsluyden van 't fort" - ,namentlijck, dat d'oppercoopman ende schipper, ofte anders de twee hoofdofficieren, daaronder sy behoren, haer tot vermaninghe van den fiscaal sullen vougen by viiff van de gerechtsluyden van 't fort."

2) Eigenlijk een achttal, althans indien men de beide luitenants van den kaptein van het fort inderdaad voor twee telt. Maar het is de klaarblijkelijke bedoeling, dat telkens diegene der beide luitenants, die vrij is van dienst, zal occupeeren. 
ordinaris-commissarissen ende gerechtluyden, dat, te beginnen met 11 Jan. 1622, wordt aangeduid als dagelijckse raet, en sedert 10 Sept. 1626 den naam draagt van Raad van Justitie, maar, omnium consensu, ondanks deze wisselende benamingen, een en hetzelfde lichaam is. Deze toestand bestaat nog bij Coen's overlijden, 20 Sept. 1629.

De vraag die wij nu, tot beslechting van het in den aanhef van deze aanteekening uiteengezet geschil, te beantwoorden hebben, is de volgende: Is deze (hoe dan ook genoemde) Raad van Justitie gedurende de bovenaangeduide periode van de ,,dagen der Compagnie”, of op eenig tijdstip dier periode, inderdaad ooit bekleed geweest ,,met het hoogste rechterlijk gezag" in het handelsrijk der Compagnie, of heeft hij altoos (gelijk ik gesteld heb) het karakter gehad van een van het Opperste Rechtscollege van dit rijk, G.G. en Rade, afhankelijke ,,mindere raad"? Het antwoord kan het best gevonden worden door een beschouwing van de verhouding van beide colleges, zooals deze blijkt uit de tot dusver gepubliceerde bronnen.

Het college van ordinaris commissarissen was, naar wij zagen, niets dan een voortzetting van de ,ordinaris” Gecommitteerde Raden, die, om een bepaalde reden, in collegiaal verband waren gebracht. Gecommitteerde Raden plachten de onder de jurisdictie van de Hooge Regeering vallende crimineele en civiele zaken te behandelen; het bevreemdt dus niet, dat ook het nieuwe college, blijkens de instellings-ordonnantie, tot behandeling zoowel van civiele als van crimineele ,breucken” bevoegd bleef ${ }^{1}$ ). Gecommitteerde Raden waren een afhankelijk hulpcollege van den G.G. en Rade; terwijl men, in civiele zaken, hun gestie door de voorzitting van een lid der Hooge Regeering voldoende gecontroleerd achtte, en zij, evenals de Schepenbank, civiele vonnissen dus zonder meer mochten vellen, moeten zij in alle zaken van pijnlijk recht, althans in halszaken, hun vonnissen, vóór de uitspraak, aan de approbatie van de Hooge Regeering onderwerpen; het valt dus te vermoeden, dat dit met het nieuwe college evenzoo het geval zal geweest zijn. Inderdaad blijkt dit vermoeden, bij toetsing, volkomen juist; verreweg het grootste deel der onderteekende sententies van Gecommitteerde Raden (= nieuwe college) nà 15 Aug. 1620 betreft ,,cleene”, civiele zaken; het eenige doodvonnis, een sententie van 9 Nov. 1620, wordt ,,rapport gedaen sijnde aen (den Heer Generaal) van 't gebesoigneerde”, slechts na verkregen approbatie geveld; doch de „,voorgelesene sententie” wordt drie dagen later door Coen weer ,,gesurcheerd”; een duidelijk bewijs, hoezeer ook het nieuwe college in dezelfde afhan-

1) Vgl. Van der Chijs: Plakkaatboek, I, p. 63. 
kelijkheid van G.G. en Rade stond als de oude Gecommitteerde Raden.

Nog duidelijker blijkt de verhouding uit de regeling van het appèl van de vonnissen van de Schepenbank. Ware het College van 15 Aug. met de hoogste rechtsmacht bekleed geworden, dan ware het uiteraard ook de aangewezen appèlinstantie geweest. Maar dit zou tegen den wensch van Heeren XVII hebben ingedruischt. „Indien”, schrijven zij in hun missive van 4 Maart 1621, ,hem iemant by voornoemde schepenen vint beswaert, die sal daervan vermogen te provoceren als nae rechten (in absentie van den Gouverneur-Generael ende Raden van Indien) aen den. Gouverneur van de stadt ende 't casteel ende syne raden, die by uuterste resort by absentie als voren met advijs van den advocaet-fiscaal daervan gehouden sullen wesen kennis te nemen" ... Dit voorschrift is geheel in den geest van de in Coen's instructie vervatte rechterlijke organisatie; het doel ervan wordt opnieuw nog eens duidelijk omschreven : ,'t selve vinden wy goed aldus te ordonneren, want vele vremde natien aldaer in de stadt commende hanteren ende genodicht sijnde op sekeren corten tijd te vertrecken, souden by provocatie aen eenigh colegie, dat buyten de stadt in verde gelegen quartieren residerende is, grote molestien comen te lyden ende van haer pretensien berooft worden, waerinne wy by desen middel vertrouwen, voorsien te hebben". Maar, voegen zij er bij, en dit is voor ons onderwerp van belang: ,als U.E. present sijn, soo sullen pertyen, die beswaert sijn, den Gouverneur van 't casteel ende syne Raden voorbygaen ende voor U.E. immediate compareren, haer administrerende goet recht, sooals. behoorlijck is". Bewindhebbers hebben dus blijkbaar aangenomen, dat de locale justieraad onder den Gouverneur, dien zij, terecht, ook in het rendez-vous opgericht hielden, ook bij aanwezigheid van G.G. en Rade niet alleen (zooals inderdaad ook geschied is) in eenigerlei vorm zou blijven bestaan, maar bovendien, wellicht op verzoek van de Hooge Regeering, als Hof van Appèl zelfstandig zou doorfunctioneeren; wat de authoriteit van G.G. en Rade als Opperste Rechtscollege zou hebben aangetast. Voor dit gevaar, de langzame verdringing van G.G. en Rade als Hoogste Rechtscollege door den localen justitieraad (resp. Raad van Justitie) hadden Heeren XVII op hunne wijze een stokje willen steken, door te gelasten, dat G.G. en Rade in hooger beroep zelf zouden rechtspreken.

Toen Coen dezen last ontving ad ij, naar wij zagen, dit gevaar reeds op een andere wijze bezworen: hij had den lokalen justitieraad (raden) zijne zelfstandigheid als plaatsvervangenden raad ontnomen, 
door hem in commissie van de Hooge Regeering, en onder haar leiding, toezicht en goedkeuring, met de behandeling van de onder haar jurisdictie vallende zaken te belasten. In dien geest heeft Coen daarop, bij ordonnantie van 18 Aug. 1620, het appèl van de vonnissen van de Schepenbank geregeld; men moest appelleeren, provoceeren of klachtig vallen bij den G.G. en Rade, die het beroep dan lieten behandelen door het nieuwe college ${ }^{1}$ ). Men zal wellicht meenen, dat deze regeling toch wezenlijk in strijd was met de latere instructie van Heeren XVII van 4 Maart 1621; doch dit is schijn: want als com-missarissen of Gecommitteerde Raden was de locale raad (raden) een verlengstuk, een aanhangsel, een pars corporis van de Opperste Rechtbank, G.G. en Rade, geworden; zijn vonnissen waren haar vonnissen. Ware het anders geweest, had Coen, na de ontvangst van de missive van 4 Maart 1621 den indruk gehad, dat zijn regeling met de ontvangen instructie onvereenigbaar was, dan zou het, bij de bekende stiptheid van Coen in het uitvoeren der bevelen van Heeren Meesters, eenvoudig ondenkbaar zijn geweest, dat hij hun last in een zoo gewichtig stuk als de organisatie der justitie genegeerd en zijn regeling ongewijzigd zou hebben gelaten. Hij moet overtuigd zijn geweest dat zijn regeling strookte met de door Heeren XVII gewenschte. Zoo zien wij dus ook in de regeling van het appèl de positie van G.G. en Rade als het met de hoogste rechtsmacht bekleede college erkend en bevestigd. Ook op indirecte wijze blijkt de verhouding tusschen het Opperste Rechtscollege en dat van ordinaris commissarissen. Afgezien van de onmiddellijke aanleiding, de samenstelling der gemengde rechtbanken, is het doel van de instelling van het nieuwe college zonder twijfel ook geweest, door een vast personeel, voor een vasten tijd benoemd, en op vaste dagen zitting houdend, meer regel en orde in de rechtspraak te brengen en de vooral in een handelsstad zoo gewenschte snelle afhandeling van zaken te bevorderen.

Maar dit doel is, helaas, anvankelijk niet bereikt. Ordinaris commissarissen zijn, qua college, aanvankelijk geen succes geweest. De oorzaak dezer mislukking was dezelfde, die reeds vroeger het uiteenvallen van zoo menigen als vast college bedoelden raad in à la fortune du jour aangewezen raden had ten gevolge gehad; die ook een goede bezetting van den Raad van Justitie tot diep in de 19e eeuw tot een permanente puzzle heeft gemaakt: de penurie aan personeel door het groote verloop ten gevolge van ziekte en uitzending. Natuurlijk had men bij de benoeming van het college van 5 Aug. 1620 zooveel moge-

1) Vgl. Besch., III, p. 985, sub 3; Van der Chijs, I, p. 65/73; Stapel, p. 53. 
lijk ,walpersoneel” gekozen; maar dat waren nog wel eens zwakke broeders wat de gezondheid betrof; de krachtige kwamen het eerst voor uitzending in aanmerking. En bovendien: alle ordinaris commissarissen waren lieden die hun rechtersambt moesten waarnemen als bijbaantje van vaak drukke werkkringen in het Compagniesbedrijf en dit alles werkte, evenals het vrijburgerschap van de leden der Schepenbank, een trouw bijwonen der zitting niet in de hand. Merkwaardig genoeg is er niet een enkele zitting waarin alle 7 op 15 Aug. benoemde commissarissen aanwezig zijn; enkele zijn zelfs nooit verschenen. Er zijn, zonder twijfel, trouwe comparanten; in de eerste plaats, Gouverneur en Edeleer De Carpentier, ook de beide opperkooplieden van het Fort, Pieter Dirckx Deucht en Abraham Van Uffelen, beiden favorieten van Coen, de laatste een toekomstige Raad van Indië, zijn geregeld present, evenals de ongeletterde houwdegen Jan Pae, de kapitein van het fort. Maar kapitein J. Gerritsz heeft het blijkbaar te druk met zijn prauwen en laat zich niet zien, en equipagemeester P. Barentsz, de arme, krijgt al spoedig ,ten respecte van sijn swaer accident in 't hooft, waervan alhier geen apparentie van beteringe is, maar dagelijkx erger wordt', mèt een bonus, verlof om te repatriëeren. Nog een derde rechtsman ontbreekt spoedig. Reeds bij de voorbereiding van de instelling van het college ontmoeten wij zekeren Mr. P. Bartsz, elders Dr. P. Batsz, in de resolutie van 15 Aug. Dr. Pauwels Barsen genoemden, fiscaal; blijkens zijn titel dus een gestudeerden jurist. Ook hij behoort onder de bij de resolutie van 15 Aut. benoemde ordinaris commissarissen; hij is ,present” in de vergadering van G.G. en Rade, waar deze resolutie is genomen, vermoedelijk wel om hem op de hoogte van de bedoeling dezer resolutie te brengen; hij neemt deel aan de zittingen van Gecommitteerde Raden van 12, 25 en 26 Aug. en onderteekent de sententies van die dagen. Daarna verdwijnt hij uit ons vizier. Is hij overleden, of is men bij het heerschend personeelgebrek genoopt geweest hem elders te employeeren? Wijst zijn benoeming er wellicht op dat men met hem, of misschien zelfs door hem met het nieuwe college, verderstrekkende plannen heeft gehad? Is hij misschien bestemd geweest, om tot plaatsvervanger van Sonck te worden opgeleid, wanneer deze mee zou moeten bij den, zeker toen reeds bij Coen voorgenomen, expeditie tot afrekening met de Bandaneezen? Of heeft men reeds in Aug. 1620 het plan gehad, dat men iets later tijdelijk tot uitvoering heeft gebracht; heeft men, tot verlichting van de taak van den advocaat-fiscaal, het nieuwe college willen maken tot een zelfstandige rechtbank alleen 
voor civiele zaken, zooals ook het zustercollege, de Schepenbank, was, en wilde men Bartsz daarbij als fiscaal laten optreden? De taak die aan het nieuwe college in zake appèl en revisie was toegedacht schijnt met deze laatste veronderstelling moeilijk te rijmen; alleen nader archiefonderzoek kan op dit punt wellicht opheldering brengen.

Hoe dit zij, naar mate het later in 't jaar wordt, gaat het met de presentie van de rechtsluyden steeds meer bergafwaarts. Groote gebeurtenissen zijn op til; ook De Carpentier en de beide luitenants krijgen het te volhandig; in de drie laatste weken van 1620 waarover wij onderteekende sententies bezitten, nemen er nog slechts vier leden onder een waarnemenden president aan de zittingen deel; en van deze vier behooren er slechts twee tot de benoemden van 15 Aug. . . . Zoo is het nieuwe college, als zoodanig, reeds voor het oudejaar op sterven na dood! De genadeslag wordt gegeven door de groote gebeurtenissen zelf: de expeditie naar Banda staat op vertrekken.

Met het oog op de naderende absentie van het Hooge College, althans van Coen en een aantal Raden van Indië, moeten natuurlijk maatregelen worden getroffen voor het beleid van de politie en de justitie in het rendez-vous. Welke deze maatregelen zullen zijn, vloeit voort uit de Instructie van 1617: de locale raad van Jacatra moet nu, als plaatsvervangende Raad, in functie treden. Bij resolutie van 4 Jan. 1621 wordt dan ook besloten, om een ,formeelen” - men lette op dit woord - ,hogen raet van 5 personen te creëren”. Maar nu geschiedt er iets, dat niet in de Instructie staat. Deze had verondersteld, dat de Hooge Regeering, bij haar vertrek naar een andere plaats, haar volle functie, d.w.z. het volledige bewind, zou blijven uitoefenen; zoodat de locale raad alleen het locale bestuur en de locale justitie zou hebben waar te nemen. Maar dit was niet meer mogelijk; het rendezvous was reeds te veel bestuurscentrum geworden, dan dat de Hooge Regeering, vandaar vertrekkend, haar functie geheel zou hebben kunnen blijven uitoefenen. Vooral was dat onmogelijk, nu zij op expeditie ging. Naast zijn bij de Instructie voorziene taak, moest aan de locale raad dus tevens het algemeen bestuur worden opgedragen. Dienovereenkomstig wordt hem de taak opgedragen, „omme het generaal maniement van Compagnies saecken soo te water als te lande, gelijck het particulier gouvernement van deze importante plaetse met goede ende nodige ordre gedurende sijn E. absentie"..." na ydereens tiyterste vermogen ten besten (te) dirigeeren en uyt (te) voeren" ${ }^{1}$ ).

1) Vgl. Besch., III,, p. 679. 
Het spreekt na onze uiteenzetting vanzelf, dat als leden van dezen Raad worden aangewezen de nog beschikbare leden van het college van 15 Aug., zoover ze niet, als Deucht en luitenant Herenthals, mee op expeditie moeten, t.w. De Carpentier, Van Uffelen en kapitein Jan Pae; het drietal wordt gecompleteerd door den Raad van Indië Dedel, die reeds voortdurend als De Carpentier's secunde was opgetreden, en thans als tweede en alternatieve president van den Hoogen Raad zal fungeeren, en de eveneens tot Raad van Indië voorbestemden commandeur Cornelis Reyersz. Schoonhooffman, die het maritieme gouvernement zal waarnemen. Door deze opschuiving houdt, na de reeds geleden verliezen, het college van 15 Aug., faute de combattants, feitelijk op te bestaan; het wordt niet ontbonden, maar verdwijnt even geruischloos als de Jacatrasche locale raad verdwenen was, nadat G.G. en Rade zich in het rendez-vous gevestigd hadden en als Opperste Rechtscollege de uitoefening der rechtspraak begonnen waren.

Zoo als vroeger uiteengezet, moet worden aangenomen, dat deze Hooge Raad, als plaatsvervanger van de Hooge Regeering de plena potestas uitoefende, zoowel bestuurs- als rechts-macht heeft bezeten. Maar daar ook hij, evenals de Hooge Regeering, het te volhandig zou krijgen, om alle rechtspraak zelf te kunnen uitoefenen, moest ook hem een hulporgaan worden ter zijde gesteld. Dit geschiedt: ,is mede goedgevonden tot soulagement van den hoogen raet een mindere of tweeden raet te formeeren"1). Dat deze raad niets anders is dan een plaatsvervanger voor het verdwenen, of wil men liever, in zijn voornaamste leden tot G.G. en Rade vervangenden Hoogen Raad gepromoveerde, college van 15 Aug., blijkt duidelijk uit de bepaling dat hij bijeen zal komen op de ,gewone rechtsdagen”, d.w.z. op dezelfde dagen, waarop bij de resolutie van 5 Sept. 1620 nader bepaald was dat het college van 15 Aug. zou bijeenkomen. Deze tweede raad zal ,,alle dagelijckxe civiele en krijgszaken ter approbatie van voors. Raeden van Indiën, (t.w. De Carpentier en Dedel) afdoen; dus geen crimineele zaken, die blijkbaar aan den Hoogen Raad zijn voorbehouden, zooals ook G.G. en Rade zekere halsmisdrijven aan de Gecommitteerde Raden (resp. het College van 15 Aug. 1620) plachten te onthouden. En de hem toevertrouwde civiele en krijgszaken alleen behoudens goedkeuring, niet van den vollen Hoogen Raad, maar alleen van de daarin zittende, achtergebleven Raden van Indië, zooals ook Gecommitteerde Raden (resp. het college van 15 Aug. 1620) deze goedkeuring van

1) Vgl. Besch., III., p. 689. 
hun vonnissen niet van G.G. en Rade, maar, in wezen, van den G.G., al of niet gehoord het college, ontvingen. De verhouding tusschen beide tweetallen colleges is dus geheel dezelfde. Daar nu de tweede raad van 4 Jan. 1621 staat tot den Hoogen Raad van dien datum, zooals het college van 15 Aug. 1620 stond tegenover de Hooge Regeering, en deze tweede raad uitdrukkelijk als ,mindere raad” wordt aangeduid, mogen wij veilig aannemen, dat ook de toenmaals nog als ordinaris commissarissen ende gerechtsluyden van 't fort aangeduide oer-Raad van Justitie een ,mindere raad” is geweest en als zoodanig is beschouwd.

„Maar”, zal men opmerken, ,het moge dan waar zijn dat G.G. en Rade oorspronkelijk in principe met de hoogste rechtsmacht in het handelsrijk zijn bekleed geweest; in de practijk is er van de uitoefening van die macht toch niet veel te merken; de Hooge Regeering heeft toch al zeer spoedig de eigenlijke rechtspraak aan een, hoe dan ook geheeten, Raad van Justitie overgelaten; na de rechtszittingen van 27 Juni tot begin Oct. 1619 is hij nooit meer als rechtbank in den engeren, eigenlijken zin des woords opgetreden!" - Toch niet!

$\mathrm{Na}$ de terugkomst van Banda betreft een van de eerste resoluties van G.G. en Rade de vernieuwing van het Schepencollege. Ook in 't Fort wordt de normale organisatie hersteld; de plaatsvervangende „,hooge” en de ,,mindere” raden verdwijnen; en mede wordt goedgevonden, ,dat men den ouden dagelicksen raet dezes forts toecomende Maendach van synen voorjarigen dienst onstaen ende wederom een nieuwen raet uyt de gequalificeerde of ficieren deses forts formeren ende authoriseeren sal” ${ }^{1}$ ). „,Voorjarige dienst”; het is dus niet de mindere raad van 4 Jan. 1621, dien men vervangt, maar wel degelijk het oude, verdwenen, college van 15 Aug. 1620, dat men volgens den conservatieven grondregel, als zijnde niet uitdrukkelijk opgeheven, nog als bestaande aanmerkt. Helaas, begint het gebruikelijke drama van voren af aan; reeds enkele maanden later is het college weer onklaar, en wordt goedgevonden, ,,alsoo by vertreck van verscheyden persoonen ditto collegie verswact ende van behoorlycke raden ontbloot blijft", ,'t selve opnieuw met andre ten overvloede te verstercken..." Natuurlijk, (en daarom behoeft het niet in eene afzonderlijke resolutie te worden besloten of goedgekeurd) nemen ook G.G. en Rade hun plaats als Opperste Rechtscollege weer in. En dat niet slechts in theorie, maar ook practisch; zij bepalen zich niet slechts

1) Vg1. Besch., III., p. 751/2. 
tot de contrôle van het werk van hun nu ,dagelijkschen" raad genoemden Raad van Justitie, maar zij spreken, in sommige belangrijke halszaken, ook zèlf recht. Dit blijkt op overtuigende wijze uit twee sententies uit het jaar 1622. De eerste sententie is die van 5 Febr. 1622, waarmee de halszaak van 't Hooft, een ernstig geval van zeeroof op vrienden, wordt berecht door G.G. en Rade ,naer daerop gehoord te hebben de advysen van den dagelycken en breden rade". De tweede sententie is van 11 Febr. 1622, waarbij een aantal gevangen Bandaneezen, na door Coen, „Gouverneur-Generaal wegen den Staet der Vereenigde Nederlanden in Indiën”, aan de ,achtbare gecommitteerde van den dagelijcxen raede deses forts Batavia tot examinatie" te zijn ,gecommitteerd”, door G.G. en Rade, gehoord ,,de advysen van den dagelijxsen ende breden rade" ten doode verwezen worden.

Wel is waar worden beide vonnissen door de adviseerende raden mede onderteekend, maar, naar uit den tekst duidelijk blijkt, de berechting geschiedt door den E. heer Generaal ende Raden van Indië, $z i j$, en niet de adviseerende raden, hooren ,,den eysch ende conclusie van den advocaat-fiscael ende de confessiën van de delinquenten; zij ,,doorzien" en overwegen "met rijpe deliberatie van rade" al 't geen ,.ter materie dienende is"; $z i j$ approbeeren niet slechts, neen $z i j$ formoeren en wijzen het vonnis. In één woord de Hooge Regeering zit in deze zaken als Opperste Rechtbank van het handelsrijk en maakt bij de instructie en beoordeeling der zaken gebruik van de hand- en spandiensten der ,mindere” raden. Deze vonnissen zijn bovendien belangwekkend, omdat zij aantoonen, dat het door mij zoowel vóór als nà 15 Aug. 1620 waarschijnlijk gedachte bestaan van twee justitieraden; een met de civiele en zekere crimineele zaken belasten smallen of dagelijkschen justitieraad, samengesteld uit de ordinaris commissarissen van 't Kasteel, en een slechts voor de berechting van zekere halszaken beroepen breeden of buitengewonen justitieraad, waarin naast de ordinaris ook extra-ordinaris commissarissen werden benoemd, ook voor later jaren moet worden aangenomen.

Ook uit deze sententies blijkt, dat de oer-Raad van Justitie althans gedurende Coen's geheele eerste ambtsperiode, een ,mindere” raad is geweest. Maar is hij dit ook nog gebleven in Coen's tweede ambtsperiode, nadat hij, bij resolutie van G.G. en Rade van 10 Sept. 1626, officiëel den titel van Raad van Justitie gekregen had; Heeft er in dien tusschentijd geen ontwikkeling plaats gevonden, ten gevolge van welke althans van dezen geattitreerden Raad van Justitie gezegd kan 
worden, dat hij met de hoogste rechtsmacht in het handelsrijk was bekleed? Een ontwikkeling heeft, onder de landvoogdij van De Carpentier, zonder twijfel plaats gevonden, hoewel wij er bedroefd weinig van weten. $\mathrm{Na}$ Coen's terugkomst in patria hadden Heeren XVII, op zijn aandrang, een rechtsgeleerde, Dr. P. Vlack, aangenomen, die als extra-ordinaris lid van den Raad van Indië uitgezonden, kort na zijn aankomst in Indië, als ordinaris lid van dien Raad, president van den dagelijkschen raad was geworden. Aan hem werd, in samenwerking met gecommitteerden uit den Raad van Justitie en uit het College van Schepenen, bij resolutie van 6 Febr. 1625 het ontwerpen van een reorganisatie van het justitiewezen opgedragen, ten gevolge waarvan o.a. ook aan het 31 Mei 1625 gereorganiseerde College van Schepenen ${ }^{1}$ ) bij resolutie van 16 Juni $1621^{2}$ ) de bevoegdheid werd toegekend tot het berechten van crimineele zaken, „wel verstaende dat haere appoinctementen in crimineele saecken sonder voorgaende approbatie van den Ed.Heer Generaal niet en sullen mogen geëxecuteerd worden". Dat, bij die gelegenheid, ook zekere wijzigingen ten aanzien van den Raad van Justitie hebben plaats gevonden, mag worden aangenomen; zeer vermoedelijk is de ordre van procederen in crimineele zaken, die bij de genoemde resolutie was gearresteerd, ook voor den Raad van Justitie verbindend gemaakt. Maar uit niets blijkt, dat in de ondergeschikte afhankelijke positie van dien Raad, zooals wij die hebben leeren kennen, eenige principiëele wijziging is gekomen. Wel was die Raad in beginsel reeds op een verhevener niveau komen te staan, dan de overige locale raden, op welk standpunt hij zich, in den loop der jaren, inderdaad zou ontwikkelen tot het met de hoogste rechtsmacht bekleede college in het handelsrijk. Dit niveau wordt aangeduid in de Instructie voor het College van Schepenen van 16/23 Aug. $1621^{3}$ ), die in art. 14 aan de Schepenbank de berechting van ,alle civiele en crimineele saecken de vrye luyden, borgeren deser stede ende vreemdelingen toucheerende" opdraagt,.... ,uytgesondert in saecken daervan het hoff ende in dese contreyen den achtbaren dagelijcxsen Raedt vant Casteel Batavia de eerste kennisse toecompt" ${ }^{4}$ ). Maar dit verhevener standpunt was niet

1) Vg1. Van der Chijs: Plakkaatbock, I., p. 125.

2) Vgl. Van der Chijs: Plakkaatboek, I., p. 126.

3) Vgl. Van der Chijs: Plakkaatboek, I., p. 127.

4) Deze zinsnede duidt de richting aan, waarin het verdere onderzoek zich zal dienen te bewegen. Met ,hoff” wordt hier kennelijk aangeduid het Hof van Holland; in Coen's gedachte staat de Dagelijksche Raad (Raad van Justitie) tot G.-G. en Rade, den gedelegeerde van den Souverein, principiëel in dezelfde ver- 
in strijd met zijn, door ons aangewezen, positie van ondergeschikte en afhankelijke mindere raad, maar, integendeel, van die ondergeschiktheid en afhankelijkheid het noodzakelijk en natuurlijk gevolg. Was de Raad van Justitie niets anders geweest, dan een Jacatrasche, en later Bataviasche raad van hetzelfde type als die welke in de overige gouverneursresidenties bestonden, dan zou zijn positie aanvankelijk minder zijn geweest: immers, zooals die andere raden zou hij dan een onafhankelijk, den G.G. en Rade vervangend, college zijn geweest. Maar zooals de zaken staan, was het college aanvankelijk een afhankelijke hulpraad geweest, die alleen die tot de purisdictie van G.G. en Rade behoorende zaken (voor)behandelde, welke dit Opperste Rechtscollege hem wel wilde toewijzen en overlaten.

Juist omdat de Raad van Justitie aanvankelijk de bijzondere justitieraad of Hof van den gedelegeerden souverein was, erfde hij, toen hij zich geleidelijk van G.G. en Rade emancipeerde, ook vanzelf hun wijdere jurisdictie. Maar deze emancipatie was in Coen's tijd nog nauwelijks begonnen. Althans in de afhankelijkheid van G.G. en Rade, die hem tot een' minderen raad van de met de hoogste rechtsmacht bekleede Hooge Regeering stempelde, was in dien tijd nog geenerlei verandering gekomen. Dit staat vast door een getuigenis 't welk niemand zal wagen te betwisten, dat van den laatsten advocaat-fiscaal onder Coen in eigen persoon. In zijn memorie aan de Bewindhebbers uit 1631 zegt deze rechtsgeleerde, zich beklagend over een ondervonden slechte bejegening: „In somma dat dese lieve Raet van Justitie, die over geen misdadigh ter weerelt, hoe groff ende swaer oock mochten mishandelt hebben, eenige macht heeft om deselve te doen peynighen, straffen, geeselen, dooden, mitsgaeders niet mach Imandt in goet mulcteren ofte met infamie noteren als met approbatie van den Gouverneur Generaenl...." ${ }^{1}$ ).

De Raad van Justitie des Kasteels Batavia is dus ook in 1629, aan het einde van Coens leven, geenszins ,,met het hoogste rechterlijk gezag" bekleed, maàr nog steeds een niet-zelfstandig rechtsprekende, veelzins ondergeschikte en afhankelijke ,mindere raad”.

houding als het Hof (van Mechelen, later) van Holland, tot den Souverein (der 17 later) 7 Provinciën. „Eerste kennisse” : er is dus nog een instantie boven den Dagelijkschen Raad (Raad van Justitie) n.1. G.-G. in Rade; de Raad is dus nog niet ,met het hoogste rechterlijke' gezag bekleed"; reeds hooger rechtscollege dan alle andere in ,deze contreyen", is hij, ten aanzien van het Hoogste Rechtscollege, G.-G. in Rade, nog steeds mindere raad. - Welke „saecken” zijn hem ter eerste kennisse voorbehouden? Bijna zeker ook de crimina majestatis.

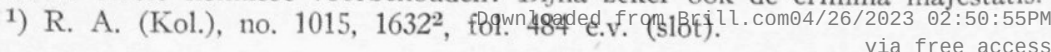


Ik heb hiermede te berde gebracht, wat ik uit de gedrukte bronnen kan aanvoeren, om mijn standpunt inzake de positie van den Raad van Justitie in Coen's tijd tegenover dat van Van Kan aannemelijk te maken. Ik hoop daarmede, in het algemeen, iets te hebben bijgedragen tot het juist verstand van de vroegste rechterlijke organisatie der Compagnie in Indië. Maar ik hoop ook iets te hebben gewonnen in het belang der zaak, die mij in 't bijzonder tot bestudeering van deze organisatie heeft genoopt: de juiste waardeering van Coen als beleider der justitie in Nederlandsch-Indië. Wij zagen dat G.G. en Rade gewoon waren sommige ,zware” zaken òf onder hun bijzonder toezicht te doen behandelen door een breeden of dubbelen raad van speciaal daartoe gecommitteerde rechters, òf wel die zelf te berechten, met advies van hun breede en dagelijksche of smalle justitieraden. Waarom dan eens de eene, dan weer de andere cynosure gekozen werd, ontgaat ons tot dusver. Maar men mag aannemen, dat de beide behandelingswijzen, voor het begrip der tijdgenooten, elkaar niet zooveel zullen hebben ontloopen. Onderzoekt men nu welk het karakter was van deze ,zware” ,breucken”, dan blijkt, dat het meest alle gevallen waren van misdaden tegen den staat. $\mathrm{Nu}$ is ook de beruchte zaak van Pieter Cortenhoeff en Sara Speckx, gelijk ik elders heb aangetoond, een geval van crimen majestatis geweest. Wanneer het nu vaststaat, gelijk uit de aangehaalde sententies van 26 en 28 Aug. zonneklaar blijkt, dat in dergelijke gevallen de meening van de mindere justitieraden, breed of smal, voor het Opperste Rechtscollege slechts de kracht van een advies heeft gehad, dan mag veilig worden aangenomen, dat dit, in het geval van Pieter en Saartje, met het z.g. vonnis van den Raad van Justitie eveneens het geval is geweest, en dat G.G. en Rade, of liever (naar Coen's practijk) G.G. in Rade, wel verre van zich aan een onbehoorlijk en willekeurig ingrijpen in den loop der ordinaris justitie te hebben schuldig gemaakt, in deze zaak volgens recht en usantie als Indië's Opperrechter heeft beslist. 